Fetal Diagnosis and Therapy
Fetal Diagn Ther 2014;35:199-203

DOI: $10.1159 / 000355653$
Received: August 22, 2013

Accepted after revision: September 17, 2013

Published online: December 7, 2013

\title{
Fetal Fraction Estimate in Twin Pregnancies Using Directed Cell-Free DNA Analysis
}

\author{
Craig A. Struble ${ }^{a}$ Argyro Syngelaki $^{b}$ Arnold Oliphant ${ }^{\mathrm{a}}$ Ken Song ${ }^{\mathrm{a}}$ \\ Kypros H. Nicolaides ${ }^{b}$ \\ ${ }^{a}$ Ariosa Diagnostics, Inc., San Jose, Calif., USA; ${ }^{b}$ Harris Birthright Research Centre of Fetal Medicine, \\ King's College Hospital, London, UK
}

\section{Key Words}

Cell-free DNA testing · Prenatal diagnosis - Fetal

aneuploidy · Twin pregnancy $\cdot$ First-trimester screening

\begin{abstract}
Objective: To estimate fetal fraction (FF) in monozygotic and dizygotic twin pregnancies. Methods: Maternal plasma samples were obtained from 35 monochorionic twin pregnancies with male fetuses (monozygotic) and 35 dichorionic pregnancies discordant for fetal sex (dizygotic) at 11-13 weeks' gestation. Cell-free DNA was extracted and chromosome-selective sequencing with digital analysis of selected regions (DANSR ${ }^{\text {TM}}$ ) was carried out. The fetal-fraction optimized risk of trisomy evaluation (FORTE'M ) algorithm was used to estimate FF using polymorphic alleles. In dizygotic twins the FORTE algorithm was modified to estimate the smallest FF contribution of the 2 fetuses. In both types of twins, FF was also determined by analysis of Y-chromosome sequences. Results: In monozygotic twins, the median total FF was $14.0 \%$ (range $8.2-27.0 \%$ ) and in dizygotic twins the median smallest FF was 7.9\% (4.9-14.0\%). There were significant associations in FF between the methods using polymorphic alleles and Y-chromosome sequences for both monozygotic $(r=0.951, p<0.0001)$ and dizygotic $(r=0.743$,
\end{abstract}

$p<0.0001$ ) twins. Conclusions: The study demonstrates the feasibility of an approach for cfDNA testing in twin pregnancies. This involves estimation of total FF in monozygotic twins and estimation of the lower FF of the 2 fetuses in dizygotic twins.

(c) 2013 S. Karger AG, Basel

\section{Introduction}

Cell-free DNA (cfDNA) testing in maternal blood has been successfully applied in singleton pregnancies and shown to provide effective screening for trisomy 21 with sensitivity of more than $99 \%$ and a false positive rate of less than $0.1 \%$ [1]. Evaluation of trisomies 18 and 13 and sex chromosome aneuploidies has also been done but with lower performance. The accuracy of cfDNA testing depends on the proportion of the fetal to maternal origin of cfDNA in maternal blood and the minimum required fetal fraction (FF) for aneuploidy assessment with current methods is $4 \%$; a lower FF could lead to a false negative result [2-6].

In twin pregnancies, cfDNA testing is more complex than in singleton pregnancies because the 2 fetuses could be either monozygotic, which are therefore genetically

\begin{tabular}{ll}
\hline KARGER & ๑ 2013 S. Karger AG, Basel \\
& 1015-3837/13/0353-0199\$38.00/0 Open carger \\
E-Mail karger@karger.com & This is an Open Access article licensed under the terms of the \\
www.karger.com/fdt & $\begin{array}{l}\text { Creative Commons Attribution-NonCommercial 3.0 Un- } \\
\text { ported license (CC BY-NC) (www.karger.com/OA-license), } \\
\text { applicable to the online version of the article only. Distribu- } \\
\text { tion permitted for non-commercial purposes only. }\end{array}$
\end{tabular}

Ken Song

Ariosa Diagnostics, Inc.

5945 Optical Court

San Jose, CA 95138 (USA)

E-Mail ksong@ariosadx.com 
identical, or dizygotic, in which case only 1 fetus is likely to have aneuploidy when present. In prenatal diagnosis by ultrasound it is possible to accurately determine chorionicity but not zygosity [7]. In monochorionic twins the two monozygotic genetically identical fetuses contribute the same alleles of cfDNA into the maternal circulation and cfDNA analysis for assessment of aneuploidy risk can be carried out in the same manner as in singleton pregnancies. In dichorionic twins the majority of cases are dizygotic. Previous studies using ultra-deep sequencing of maternal plasma cfDNA in dizygotic twins reported that each fetus can contribute different amounts of cfDNA into the maternal circulation and this could vary by nearly 2 -fold [8]. It is therefore possible that in a dizygotic twin pregnancy discordant for aneuploidy, the FF of the affected fetus is below the threshold of $4 \%$ for successful cfDNA testing. This could lead to an erroneous result of low risk for aneuploidy because a high contribution from the disomic co-twin could result in a satisfactory total FF. For example, if the total FF in a dizygotic twin pregnancy discordant for trisomy 21 is $9 \%$ and it is assumed that each fetus contributes equal amounts of cfDNA into the maternal circulation, but in reality there is a contribution of $6 \%$ from the euploid fetus and 3\% from the trisomic one, cfDNA testing could wrongly classify the fetuses as euploid.

We propose that in monochorionic twins the approach to cfDNA testing for aneuploidies could be the same as in singleton pregnancies, but in dichorionic twins the approach should be modified to take into account the FF of the twin with the lower contribution to cfDNA in maternal blood. This study describes a directed cfDNA analysis approach to estimate FF in monozygotic and dizygotic twin pregnancies.

\section{Methods}

\section{Study Population}

Maternal venous blood samples were obtained at 11-13 weeks' gestation from twin pregnancies undergoing first-trimester screening for trisomies by a combination of fetal nuchal translucency thickness and maternal serum-free $\beta$-human chorionic gonadotropin ( $\beta$-hCG) and pregnancy-associated plasma protein-A (PAPP-A) [9-11]. All patients gave written informed consent to provide samples for research which was approved by the NHS Research Ethics Committee. Gestational age was determined from the measurement of the crown-rump length (CRL) of the larger twin and chorionicity was determined by examining the inter-twin membrane at its junction with the placenta $[7,12]$.

Blood samples were collected in ethylenediaminetetraacetic acid BD Vacutainer ${ }^{\mathrm{TM}}$ tubes (Becton Dickinson UK Ltd, Oxford, $\mathrm{UK}$ ) and within $15 \mathrm{~min}$ of collection they were centrifuged at
2,000 $\mathrm{g}$ for $10 \mathrm{~min}$ to separate plasma from packed cells and subsequently at $16,000 \mathrm{~g}$ for $10 \mathrm{~min}$ to further separate cell debris. Plasma samples were divided into $0.5-\mathrm{ml}$ aliquots in separate Eppendorf tubes which were labeled with a unique patient identifier and stored at $-80^{\circ} \mathrm{C}$ until subsequent analysis.

For the present study we searched our database of stored samples and identified 35 cases of monochorionic twins and 35 cases of dichorionic twins discordant for fetal sex. In all cases the pregnancies resulted in phenotypically normal neonates that were assumed to be euploid. Plasma samples ( 4 tubes of $0.5 \mathrm{ml}$ per patient) were sent overnight on dry ice from London, UK, to the USA (Ariosa Diagnostics, Inc., San Jose, Calif., USA) for cfDNA analysis.

\section{Analysis of Samples}

cfDNA was extracted from maternal plasma samples and chromosome-selective sequencing, referred to as digital analysis of selected regions (DANSR ${ }^{\mathrm{TM}}$ ), against loci in the human genome was performed as previously described [13]. The DANSR assays include a set of 192 single nucleotide polymorphic (SNP) loci on chromosomes 1-12, where two middle oligonucleotides differing by one base were used to query each SNP. SNPs were optimized for minor allele frequency in the HapMap-3 dataset (http://hapmap. ncbi.nlm.nih.gov/). DANSR assay products were sequenced using the Illumina HiSeq 2000 as previously described [13].

Informative polymorphic loci were defined as loci where fetal alleles differ from maternal alleles. Because DANSR exhibits high allele specificity, informative loci were readily identified when the fetal allele proportion of a locus was measured to be between 1 and $25 \%$. When the fetal contribution to the cfDNA in maternal blood is at $4 \%$ or higher, corresponding to a $2 \%$ fetal allele proportion, a truly informative locus has a greater than $95 \%$ chance of having a measured fetal allele proportion greater than $1 \%$.

The fetal-fraction optimized risk of trisomy evaluation $\left(\right.$ FORTE $\left.^{\mathrm{TM}}\right)$ algorithm was used to assay non-polymorphic and polymorphic loci, where fetal alleles differ from maternal alleles, enabling simultaneous determination of chromosome proportion and FF [13]. In dizygotic pregnancies, the original FORTE algorithm for singleton pregnancies was modified to estimate the smallest FF contribution of the 2 fetuses and this was used to establish the expected change in chromosome proportion for trisomic samples. Estimation of the smallest FF was accomplished by identifying the lower 45th percentile of polymorphic DANSR assays with a non-maternal allele and using these assays as representative of FF.

In both monozygotic and dizygotic pregnancies FF was also measured using 32 non-polymorphic loci on the Y-chromosome. Median counts from these assays were compared with median counts of non-polymorphic DANSR assays developed for chromosomes 13,18 and 21 to estimate the FF.

\section{Results}

The characteristics of the monozygotic and dizygotic twin pregnancies are outlined in table 1 . The median total sequencing counts per sample was 2.89 million (range $2.52-3.30$ ) with a median coverage of 874 counts (range 768-1,004) per genomic locus. 


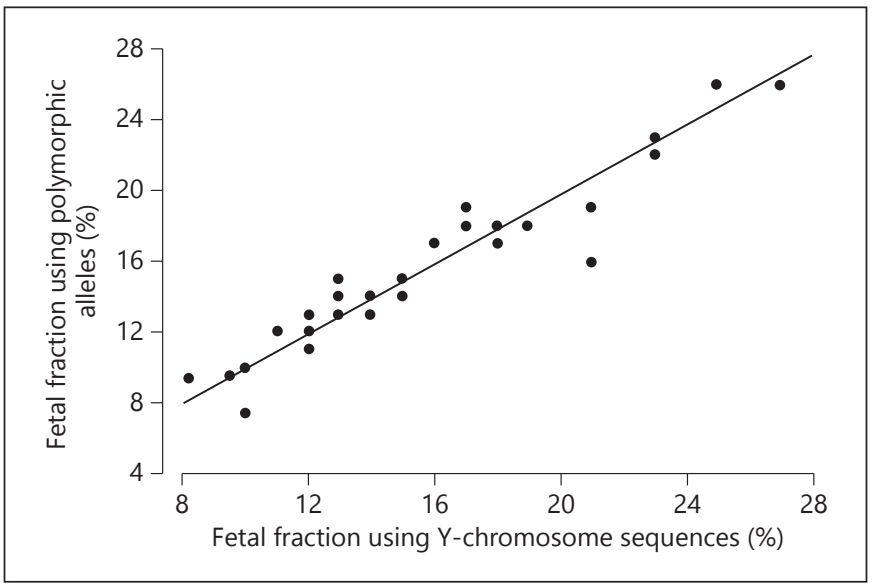

Fig. 1. Total FF estimate in monozygotic twins using polymorphic alleles and Y-chromosome sequences.

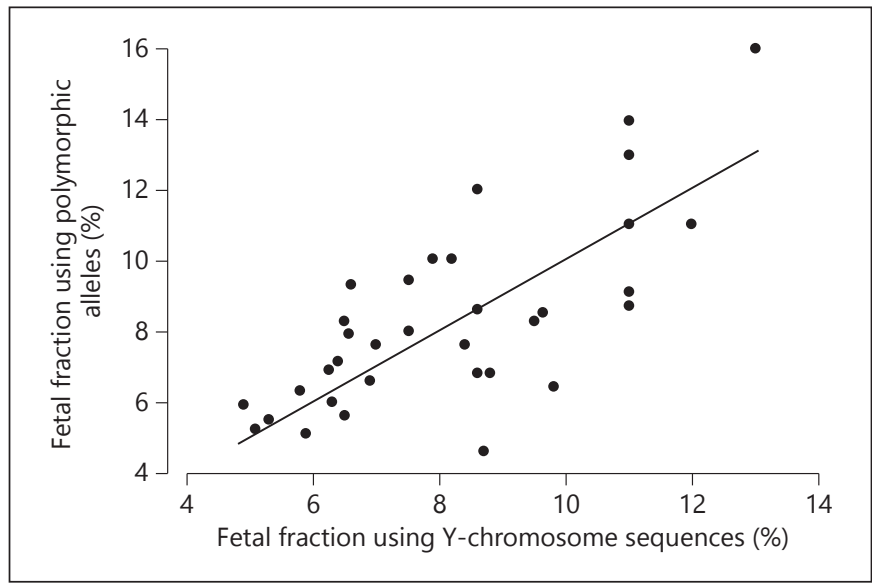

Fig. 2. Lower FF estimate in dizygotic twins using polymorphic alleles and Y-chromosome sequences.

Table 1. Characteristics of the monozygotic and dizygotic twin pregnancies

\begin{tabular}{lcc}
\hline Characteristic & Monozygotic $(\mathrm{n}=35)$ & Dizygotic $(\mathrm{n}=35)$ \\
\hline Maternal age, years & $31.8(30.0-36.0)$ & $33.0(29.2-36.3)$ \\
Maternal weight, kg & $68.5(62.0-79.0)$ & $64.5(59.4-74.0)$ \\
Maternal height, cm & $167.6(162.6-171.9)$ & $164.0(159.0-167.6)$ \\
Racial origin & & \\
Caucasian & $23(65.7)$ & $23(65.7)$ \\
Afro-Caribbean & $6(17.1)$ & $9(25.7)$ \\
South Asian & $1(2.9)$ & $1(2.9)$ \\
East Asian & $1(2.9)$ & $1(2.9)$ \\
Mixed & $4(11.4)$ & $1(2.9)$ \\
Cigarette smoker & $2(5.7)$ & $1(2.9)$ \\
Mode of conception & & $26(74.3)$ \\
Spontaneous & $16(45.7)$ & 0 \\
In-vitro fertilization & $2(5.7)$ & $9(25.7)$ \\
Ovulation drugs & $17(48.6)$ & $91(88-94)$ \\
Gestational age, days & $92(90-96)$ & $67.6(62.4-74.1)$ \\
CRL of the larger fetus, mm & $69.1(63.7-77.2)$ & $7.41(6.10-9.95)$ \\
PAPP-A, IU/ml & $6.44(4.49-10.44)$ & $77.50(50.20-98.80)$ \\
Free $\beta$-hCG, IU/ml & $47.05(39.25-86.75)$ & \\
\hline
\end{tabular}

Median (IQR) or $\mathrm{n}(\%)$ values are shown.

In the monozygotic twin pregnancies, the median total FF, determined using polymorphic alleles, was $14.0 \%$ (range $8.2-27.0 \%)$ and there was a highly significant association with the fraction determined by Y-chromosome counts $(\mathrm{r}=$ $0.951, \mathrm{p}<0.0001$; fig. 1 ). In the dizygotic twin pregnancies, the median lower FF of the 2 fetuses, using a modified FORTE algorithm, was 7.9\% (range 4.9-13.0\%) and there was a significant association with the fraction determined by $Y$-chromosome counts ( $r=0.743, p<0.0001$; fig. 2$)$.

Fetal Fraction Estimate in Twin

Pregnancies

\section{Discussion}

This study demonstrates the use of chromosome-selective sequencing of $\mathrm{cfDNA}$ in maternal blood to estimate $\mathrm{FF}$ in twin pregnancies. In monochorionic twins, cfDNA analysis was carried out in a similar manner as in singleton pregnancies and the total FF was estimated because the 2 fetuses contribute the same alleles of cfDNA into the maternal circulation. In dichorionic dizygotic twins, the 
smallest FF contribution of the 2 fetuses was estimated and this was used to establish the expected change in chromosome proportion for trisomic samples. This approach could potentially increase the number of pregnancies that are not given a result, because the FF is less than $4 \%$, but reduces the likelihood of providing false negative results.

In both monozygotic and dizygotic twins there were significant associations in the FF estimated by polymorphic alleles and that using Y-chromosome sequences. The higher correlation in values by the two methods in monozygotic than dizygotic twins is because in the former, both fetuses were male and the total FF was considered. The lower correlation in dizygotic twins is likely to be because the method using Y-chromosome sequences reflected the contribution to maternal plasma cfDNA of the male fetus but the method using polymorphic alleles reflected the lower contribution between the 2 fetuses which could have been either male or female.

The finding that in monozygotic twins the median total FF was $14 \%$ and in dizygotic twins the median lower FF of the 2 fetuses was $8 \%$ is compatible with the $10 \%$ value in singleton pregnancies at 11-13 weeks' gestation [14, 15]. The likely source of fetal cfDNA in maternal plasma is dying cells in the placenta [16] and consequently the number of apoptotic cells would be proportional to the placental mass. We have previously reported significant associations between FF and serum-free $\beta$-hCG and PAPP-A whose concentration provides an indirect measure of placental mass $[15,16]$. In monochorionic twins, the levels of serum-free $\beta$-hCG and PAPP-A, expressed as multiple of the median (MoM) in singletons, increase from about 1.0 $\mathrm{MoM}$ each at 9 weeks' gestation to $2.0 \mathrm{MoM}$ for free $\beta$-hCG and 1.5 MoM for PAPP-A at 13 weeks $[17,18]$. In dichorionic twins the levels of these metabolites are higher and they both increase from about $1.5 \mathrm{MoM}$ at 9 weeks to $2.0 \mathrm{MoM}$ at 13 weeks. Consequently, the total $\mathrm{FF}$ in monochorionic twins would be expected, as found, to be about 1.5 times rather than twice as high as in singletons. Similarly, the lower FF in dizygotic twins would be expected, as found, to be less than the value in singletons.

In monochorionic twins, effective screening for aneuploidies by cfDNA testing in maternal blood can be applied as in singleton pregnancies provided the total FF contributed by both fetuses is at least $4 \%$. In dizygotic twins, accurate assessment of risk necessitates that the minimum FF of $4 \%$ is reached by each of the 2 fetuses. In three previous studies reporting on the use of cfDNA testing in screening for trisomies in twin pregnancies it was assumed that each fetus had contributed adequate amounts of cfDNA into the maternal circulation $[5,19$,
20]. Supportive evidence, that each of the fetuses in a twin pregnancy is producing a similar amount of cfDNA as in singleton pregnancies, was provided by the results of studies which used a Y-chromosome-associated gene as a marker for fetal DNA and reported that the fetal cfDNA concentration in maternal plasma in twin pregnancies with mixed fetal sex is the same as in singleton male pregnancies $[21,22]$.

In contrast to the results of the studies using the $\mathrm{Y}$ chromosome-associated gene as a marker for fetal DNA, studies using massively parallel shotgun sequencing of cfDNA in maternal plasma, to look across multiple genomic regions for differences between the fetuses in dizygotic twins, reported that there are large differences in the contribution of the 2 fetuses to cfDNA in maternal blood $[8,23]$. In the massively parallel shotgun sequencing studies it was necessary to carry out ultra-deep sequencing with a median of 431 million sequencing reads to achieve a median of 530-fold coverage at each genomic locus. An advantage of the directed cfDNA analysis with DANSR used in our study is the higher efficiency with DNA sequencing which requires only 2.89 million sequencing reads to achieve a median of 874 -fold coverage at each genomic locus to provide a reasonable estimate for the lower FF of the 2 fetuses. We believe that estimation of the lower FF is what matters clinically, because the potential source of an erroneous result from cfDNA screening for aneuploidies in dizygotic twins is failure to recognize the cases with a satisfactory total FF but with an unsatisfactory lower FF for 1 fetus of less than $4 \%$.

Fetal aneuploidy assessment with cfDNA analysis has proven to be clinically useful in singleton pregnancies. While twin pregnancies pose some additional complexity, it is likely that cfDNA analysis will also be clinically useful in this population. However, the proposed approach for cfDNA testing in monozygotic and dizygotic twins requires further investigation in clinical implementation studies.

\section{Acknowledgements}

The study was supported by a grant from The Fetal Medicine Foundation (UK Charity No. 1037116). Analysis of samples was performed at their own expense by Ariosa Diagnostics, 5945 Optical Court, San Jose, CA 95138, USA.

\section{Disclosure Statement}

A.S. and K.H.N. have no conflicts of interest to disclose. C.A.S. and A.O. are employees of Ariosa Diagnostics and K.S. is an employee and board member of the company. 


\section{References}

1 Gil MM, Quezada MS, Bregant B, Syngelaki A, Nicolaides KH: Cell-free DNA analysis for trisomy risk assessment in first-trimester twin pregnancies. Fetal Diagn Ther, E-pub ahead of print.

-2 Chiu RW, Akolekar R, Zheng YW, Leung TY, Sun H, Chan KC, Lun FM, Go AT, Lau ET, To WW, Leung WC, Tang RY, Au-Yeung SK, Lam H, Kung YY, Zhang X, van Vugt JM, Minekawa R, Tang MH, Wang J, Oudejans CB, Lau TK, Nicolaides KH, Lo YM: Non-invasive prenatal assessment of trisomy 21 by multiplexed maternal plasma DNA sequencing: large-scale validity study. BMJ 2011;342:c7401.

-3 Ehrich M, Deciu C, Zwiefelhofer T, Tynan JA, Cagasan L, Tim R, Lu V, McCullough R, McCarthy E, Nygren AO, Dean J, Tang L, Hutchison D, Lu T, Wang H, Angkachatchai V, Oeth P, Cantor CR, Bombard A, van den Boom D: Noninvasive detection of fetal trisomy 21 by sequencing of DNA in maternal blood: a study in a clinical setting. Am J Obstet Gynecol 2011;204:205.e1-e11.

4 Palomaki GE, Kloza EM, Lambert-Messerlian GM, Haddow JE, Neveux LM, Ehrich M, van den Boom D, Bombard AT, Deciu C, Grody WW, Nelson SF, Canick JA: DNA sequencing of maternal plasma to detect Down syndrome: an international clinical validation study. Genet Med 2011;13:913-920.

5 Sehnert AJ, Rhees B, Comstock D, de Feo E, Heilek G, Burke J, Rava RP: Optimal detection of fetal chromosomal abnormalities by massively parallel DNA sequencing of cellfree fetal DNA from maternal blood. Clin Chem 2011;57:1042-1049.

6 Ashoor G, Syngelaki A, Wagner M, Birdir C, Nicolaides KH: Chromosome-selective sequencing of maternal plasma cell-free DNA for first-trimester detection of trisomy 21 and trisomy 18. Am J Obstet Gynecol 2012;206: 322.e1-e5.

7 Sepulveda W, Sebire NJ, Hughes K, Odibo A, Nicolaides KH: The lambda sign at 10-14 weeks of gestation as a predictor of chorionicity in twin pregnancies. Ultrasound Obstet Gynecol 1996;7:421-423.
$>8$ Leung TY, Qu JZ, Liao GJ, Jiang P, Cheng YK, Chan KC, Chiu RW, Lo YM: Noninvasive twin zygosity assessment and aneuploidy detection by maternal plasma DNA sequencing. Prenat Diagn 2013;33:675-681.

$>9$ Nicolaides KH: Screening for fetal aneuploidies at 11 to 13 weeks. Prenat Diagn 2011;31 7-15.

10 Wright D, Syngelaki A, Staboulidou I, de Cruz JJ, Nicolaides KH: Screening for trisomies in dichorionic twins by measurement of fetal nuchal translucency thickness according to the mixture model. Prenat Diagn 2011;31:16-21.

11 Madsen HN, Ball S, Wright D, Tørring N, Petersen OB, Nicolaides KH, Spencer K: A reassessment of biochemical marker distributions in trisomy 21 affected and unaffected twin pregnancies in the first trimester. Ultrasound Obstet Gynecol 2011;37:38-47.

$>12$ Robinson HP, Fleming JE: A critical evaluation of sonar crown-rump length measurements. Br J Obstet Gynaecol 1975;182:702710.

13 Sparks AB, Struble CA, Wang ET, Song K, Oliphant A: Noninvasive prenatal detection and selective analysis of cell-free DNA obtained from maternal blood: evaluation for trisomy 21 and trisomy 18. Am J Obstet Gynecol 2012;206:319.e1-e9.

14 Faas BH, de Ligt J, Janssen I, Eggink AJ, Wijnberger LD, van Vugt JM, Vissers L, Geurts van Kessel A: Non-invasive prenatal diagnosis of fetal aneuploidies using massively parallel sequencing-by-ligation and evidence that cell-free fetal DNA in the maternal plasma originates from cytotrophoblastic cells. Expert Opin Biol Ther 2012;12(suppl 1):S19S26.

15 Ashoor G, Poon L, Syngelaki A, Mosimann B, Nicolaides KH: Fetal fraction in maternal plasma cell-free DNA at 11-13 weeks' gestation: effect of maternal and fetal factors. Fetal Diagn Ther 2012;31:237-243.
16 Ashoor G, Syngelaki A, Poon LC, Rezende JC, Nicolaides KH: Fetal fraction in maternal plasma cell-free DNA at 11-13 weeks' gestation: relation to maternal and fetal characteristics. Ultrasound Obstet Gynecol 2013;41: 26-32.

17 Wright D, Spencer K, Kagan KO, Tørring N, Petersen OB, Christou A, Kallikas J, Nicolaides KH: First-trimester combined screening for trisomy 21 at 8-13 weeks. Ultrasound Obstet Gynecol 2010;36:404-411.

18 Madsen H, Ball S, Wright D, Tørring N, Petersen O, Nicolaides K, Spencer K: A re-assessment of biochemical marker distributions in T21 affected and unaffected twin pregnancies in the first trimester. Ultrasound Obstet Gynecol 2011;37:38-47.

-19 Canick JA, Kloza EM, Lambert-Messerlian GM, Haddow JE, Ehrich M, van den Boom D, Bombard AT, Deciu C, Palomaki GE: DNA sequencing of maternal plasma to identify Down syndrome and other trisomies in multiple gestations. Prenat Diagn 2012;32:730734.

20 Lau TK, Jiang F, Chan MK, Zhang H, Lo PS, Wang W: Non-invasive prenatal screening of fetal Down syndrome by maternal plasma DNA sequencing in twin pregnancies. J Matern Fetal Neonatal Med 2013;26:434437.

21 Smid M, Galbiati S, Vassallo A, Gambini D, Ferrari A, Restagno G, Viora E, Pagliano M, Calza S, Ferrari M, Cremonesi L: Fetal DNA in maternal plasma in twin pregnancies. Clin Chem 2003;49:1526-1528.

-22 Orendi K, Klein K, Krampl-Bettelheim E, Nuk M, Holzapfel-Bauer M, Magnet E, Griesbacher A, Lang U, Pertl B: SRY-specific cellfree fetal DNA in maternal plasma in twin pregnancies throughout gestation. Placenta 2011;32:611-615.

23 Qu JZ, Leung TY, Jiang P, Liao GJ, Cheng YK, Sun H, Chiu RW, Chan KC, Lo YM: Noninvasive prenatal determination of twin zygosity by maternal plasma DNA analysis. Clin Chem 2013;59:427-435.
Fetal Fraction Estimate in Twin Pregnancies
Fetal Diagn Ther 2014;35:199-203 